経営史学

さ力な何いるな録に

せの問出本てで分染関海

よ 変題他稿 の あ 析二連

方化のの澥 ら方応る業

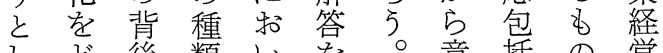

乞ど後類い学。意括の営

たの注のて見言思的では

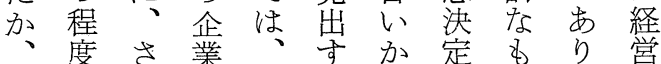

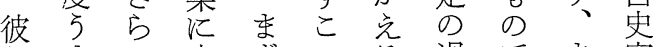

らま充ずとる過でま家

はく次用、がな程あたに

、予のしイでらやる営と

ご測よたギきば資な業っ

のし 5 方りる、本ら活て

程党ながスか一運ば動稔

$\begin{array}{ll} & \widehat{\text { 特 }} \\ \text { 海 } & \text { 別 } \\ & \text { 容 } \\ & \text { 稿 }\end{array}$

運

業

経

営

度た多よのぞ連用、のり

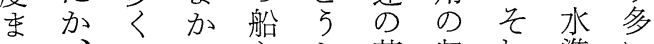

で、のっ主か基収机準い

伝彼要たがは礎益はのの研

統ら素の本、資性様変究

的は㔔加当経料や令化分

業どあどに営に企な无野

務のるら彼史対業程々で

を程こ加ら家しの度の市

放度々 と资て二資る

萧積

乙極明 万金なま的析のそ

新的か閏をのく性の収れ

しにで題最で問質材益は

い技あ か子出題に料力船

業術らら生るを関と舶

務的 5 出産口投方な与

革。発的将る方党

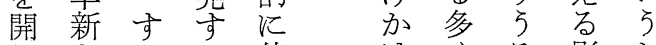

始をなる使注くるる影少

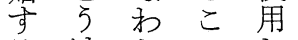

るけらとし

経 質㤎にち

意れ船乙の 営問普関で

㔖主よか企の无る認

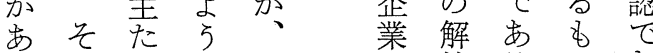

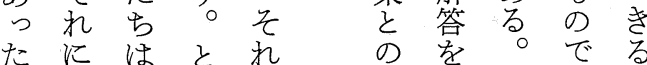

た注とれれ の経吉々市

かる よ そ ら

まてので彼

た能船、

最率隊々 の

後をのの資

兽收占本

済出しる。団

的守て。只

潜こ、海 資

在々另運 本

J がの 羓の゙ 


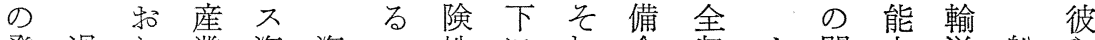
発過り業海海の性に机金收イ関力送船ら 展去、㤎運運がにこがの に六英好業企常 対 部全投のリに積れ の彼

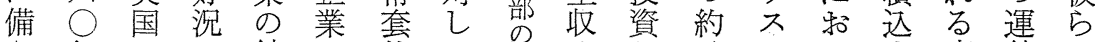
学のの 純の 的て 会入分八のいま商航の 間国 項收 経 政 備 社 額 500 定て る 品 は資 利に際点益営 策 爷でに得 \% 期評べに高金

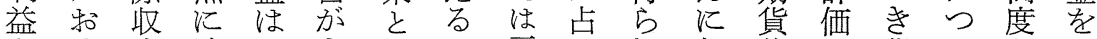

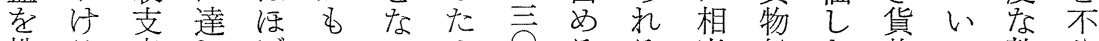

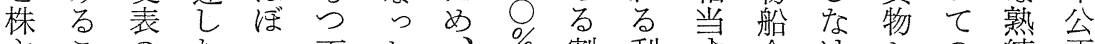

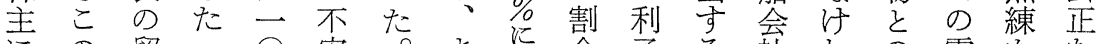
にの貿一○安。ま古子る社れの需をな 償よ易九 定九岕㤎営にば各要要競 還 万外兰百な 一 低々業関な時の季争 乙な収七万性部減落机收守 5 点度るの た激入年ポ格、少すず益るずに合計破

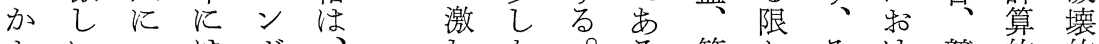

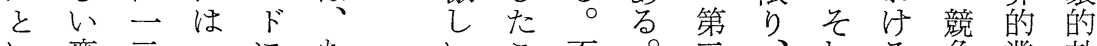

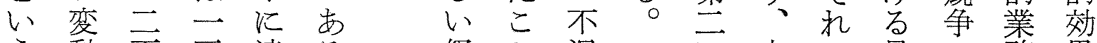

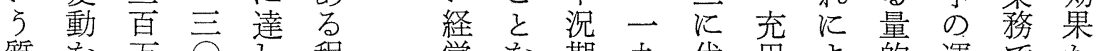
質を方 $\overrightarrow{0}$ 程営を期九代用よ的運でか

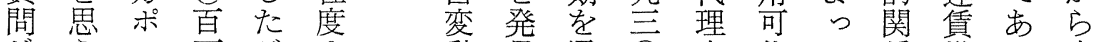

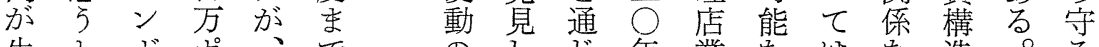
生々゙゙ポ、ですしで年業なはな造のる

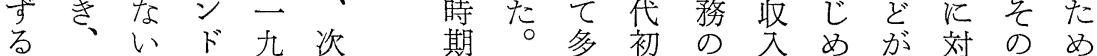

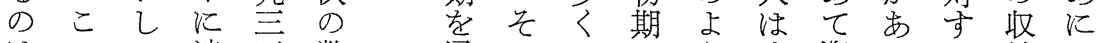
はの二達三数 通の の の 万次資るる 益ど 当産五し年字它結海々なの本。有力口 然業百た不少て果運机サ三収船效はむ

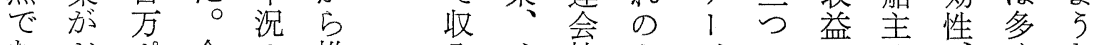

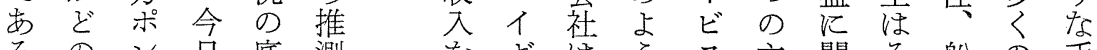
ろのン日底测峃ギはう釉の手

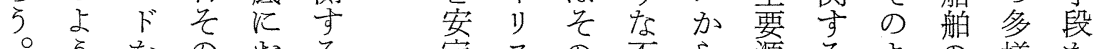

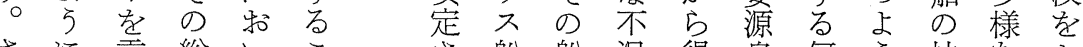
さに貢総いこ导船船況得泉何 きし 献收てと主舶期 ら 加らな 術要っ にてし益はがる稼にれらか諸的因た 引既て注で六て動は、る得の要效にか

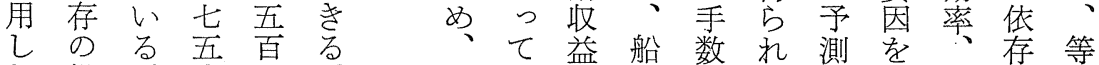
た投。号方。 数 下 百ポ 一 字資 万ン九 は本 ポド三

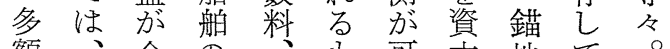
額、全の斿可本地て。 の一收営その能支で物 準部入業しでに出提り

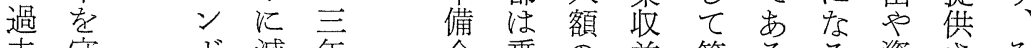
去守 ド減 年 金乗 の 益第る る 資さ兄

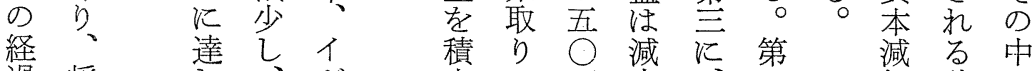

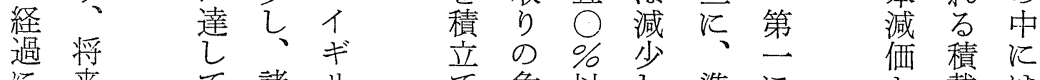
汇来諸リ光危以準に、 載注 
経棠史学

は脱するの特す的年と年時なてのつ い退る試延定運建地イ代の类期りは年い ずしこみ払種賃造位ギ末後でに上不でて れとに運類の計学りにのには昇海市信

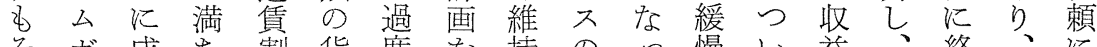
そガ成ら 割貨度を持のっ 慢い益、終、に のル功て 帍物な 推し 船て なて はと始々 足 收・乙い変進な主の恢は比のしのる 益グたるとった動しけたた復、較間、後手

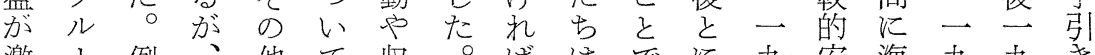
激了。例、他て収。ばはでに九安海九九き

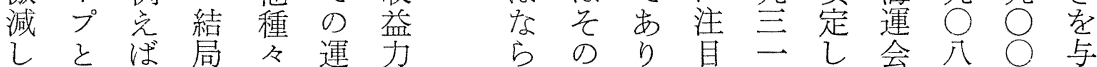

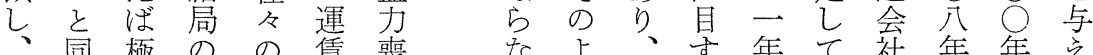

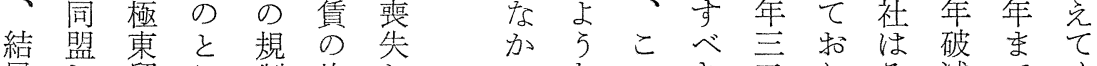

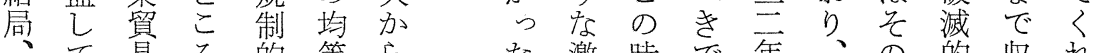
七易万的等 5 激時で年、の的收れ

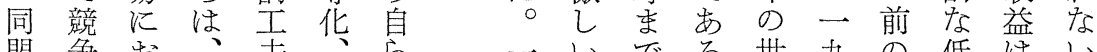
盟争和、夫者 参をい同の同学般景に方界云時收僅。 加激て 盟た守 守気戦。的六期益加々 企化、制め航る化变時ま不年にになこ 業さ二度の路た ギ動徵す沅と蒙落下下で 数よ 八

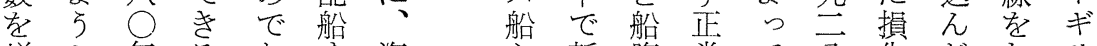
増之年る 加図代だっる連礼不な生年の的 さっ千汗た諸諸恏い足状じは多しり海 せたャ包。会会沅発と態たかくかな運 てが、括イ社社期展の㤎收なををしが業 新、ナ的ギ間は学垔支益り償一ら收 七そ・なリで船準準影配ののう九変益 いのミもスの主 備 備響守激好こ一動の

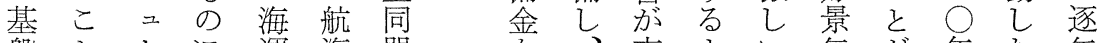

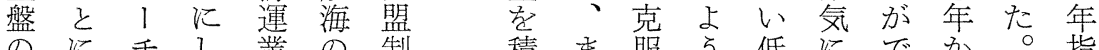
のにチし、業の制積ま服ら低にでか。指 上よュ、の割度、文たざた恵きら一標

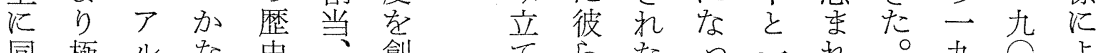

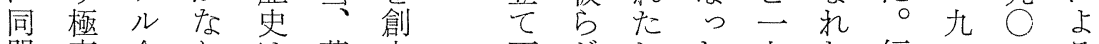

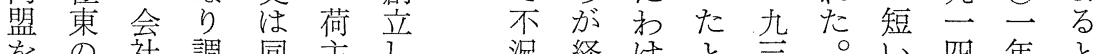

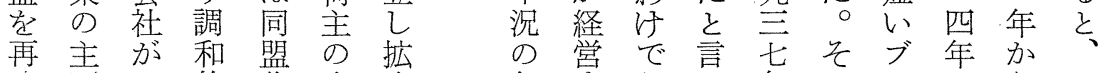

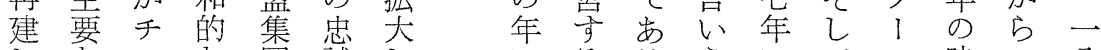
しななな団誠しるるる な定イ航を竞た諸。るどそに期九公

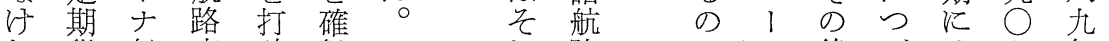
机貨船事破保こ路こは後づは七。年

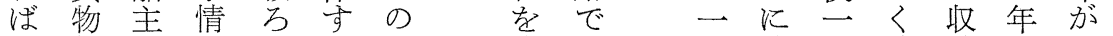

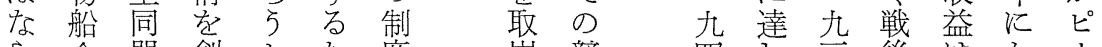
な 企盟創尔 た 度 崩競 
況ンたと船か の設ン規る王しいまた のス。市体ら一間計ポ則と立たたた南っ

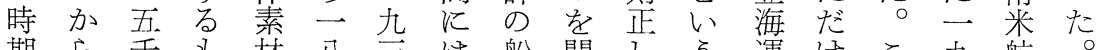

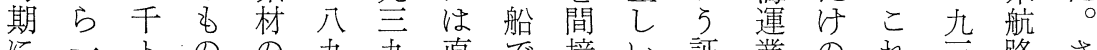
に二トのの九直で接い証業のれ至路さ も九ンで鉄七年接整的サ拠同こ ら 0 同 非○の市か年以的備に渻との年盟に 経五定つらの前な す 堌ビ何調で事代と一 済年期た鋼時に関る大ス查あ例初の八 的の貨。へ期つ連たさをる 委っもも期間九 な○物この无い夰めせ提生員た他にに○

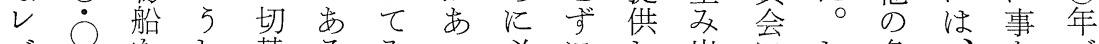

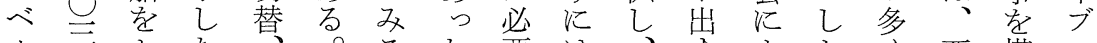
ル三とたな要は、拉よかく西構口

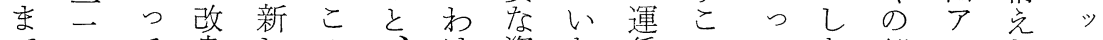

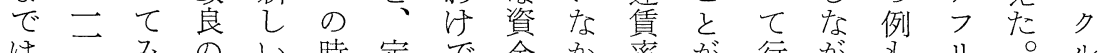

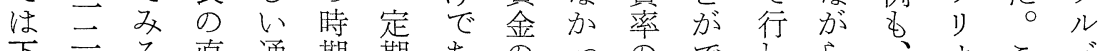
下 落る 直通期期 あ 落ンと接風の貨る割た安き机、要線の 声 人的装再物。当し定なた同守同南ク なにトな 置建船虔、性か 同盟る 盟米不

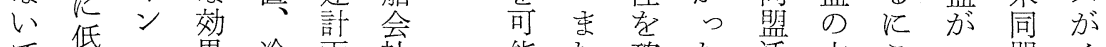
で隼・果冷画社能た確た活少こ盟イ

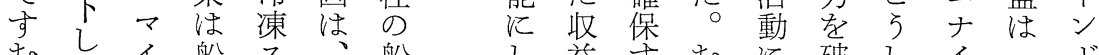
むた 船 ス、船し益导むに破しイ—ド

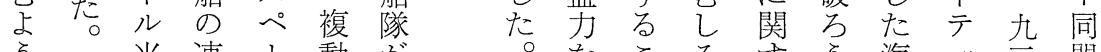

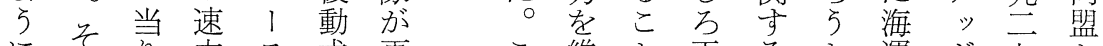

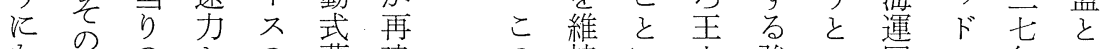
な結の と の 蒸建持に立強い同・年の

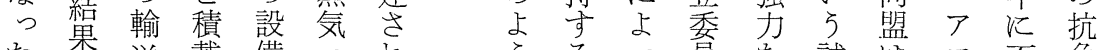
た果送載備エれれ 航原能新 ジ た

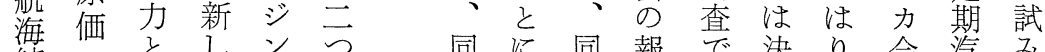

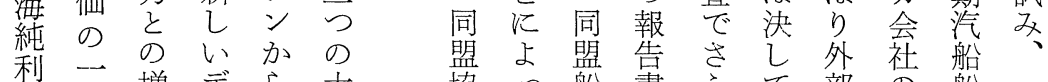

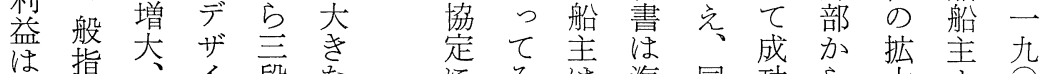

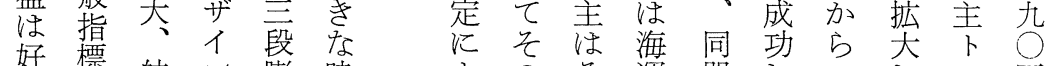

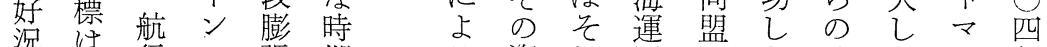

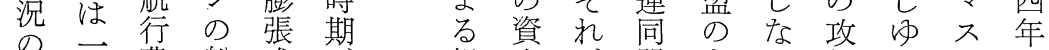

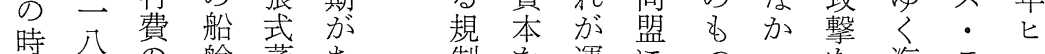
期九 の 艙蒸

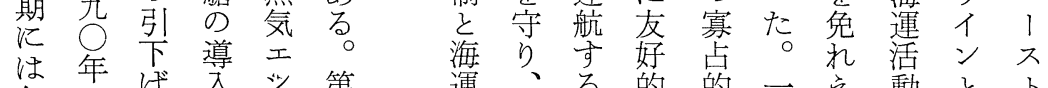

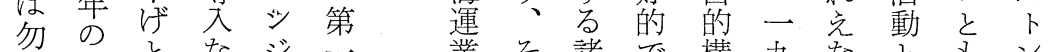
論○とな ま

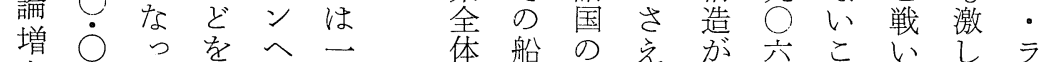

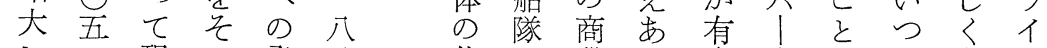
し二現の発八能父業つ害○学づ争ン

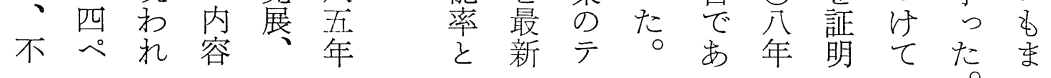


経 営 史 学

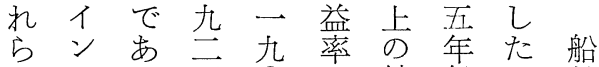
のドつ四 $\bigcirc \frown$ 純船か 船 航航た年二吾收主ら、の 路 路少以年割益洛、建 に、、降か割をる、最造 抒メしはら以間資後・ 壮キか全云た違本に運

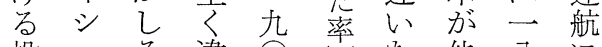
投コ气違 ○等な他八に 資湾れつ八のくの割 飞航とて年指挙投五当 つ路はいの標げ資「ら い別る間を称分一れ て東に。は見ば野九流 の印若一、るな司入

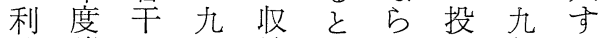
益諸の晋益なな゙年る の島航 - 力 一 加らの資 期 航 路 年が八っれ間金 待路が和下九たた、美 はにるよ向五。場船量 満特はびき门イ合主は、 さいやーの れて收九変九リ同営主 なと益晋動—スじの至 からを者を四の师し っで生年続年最沙益て たあ文の汀の大の性ど ○得不て間海收㤎の したな況い運益どよ か。くのたど企をの ら し現な末にの業確よな 二実っ曾政无保方影 方のて有拘路社守に響 收いのらでにる変力 中益る激ずもつた化に 国は徵し そ五いるめしょ 期候さら \%てにたる

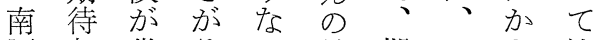
阿收幾々の純期三を決 益つ5で收堼 $\vec{\bigcirc}$ 検定 ブにもしあ益收年討导 ラはあたるは益間しる ジるつ事。達率にての ルかた態し成で瓦拉か 、に。のか岂ならりを 西及々重し机以年引若 印ばれ要なて現率。午 度ずはながい実五一明 濠こ特原ら る
るきあり年

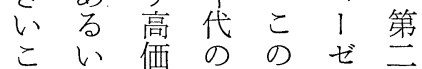

とはなイ新ル期

をま石ギし・の

実た油りい土再

証石を ス 形ン建

乙 油 燃が態ジは

たを料依のン一

。然之然動に九

イ料すと力ょ二 ギとるしえる 四

リす新ての推 !

スるし石切進二

の夕い炭替替昆

商、エをば年

船ビン 基、ちの

隊ンジ礎復ら間

がをンと動㤂に

デ船の 文式優行

イに利るかれわ

1装点経 らてれ

ゼ備学済戛いた

ルし上で段る。

-た迴あ膨かこ

エ会っっ張との

ン社たた式い時

ジでわこのう期

ンは村と祭に

を、でにれ題沶

装平 あよへ注

備均るるのつる

投。之切い重

る沓しこ替て 要

よ資から汪のな

万本しがど論変

当な大二争化

ならがき般の柱

るでら、、华中菠

は新乇安な実穿

第式 1 価か現工

二船タなっしン

次の 船石た た

大方を炭。的。

戦㤎建 そ泟

後收造いれ的

こ 益 じ

之よ 会点九 進

あ゙ り 社 が 
第 2 巻第 3 号

ン 訳

. 者

E あ

亡

イ゙き

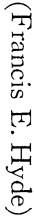

博

䓛

リ

ヴ

7

1

大

D)

千

ド

ッ

経

済

教

授

\&

b

イ

즌

の

経
動運まに業のの広賢キのの場州 を企たと界年可沉経明シで合航 含業そっのか能な営なる、路 さののて衰ら性分史や湾船は为

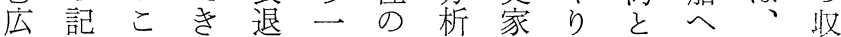
沉録と学九变手の方少の一益

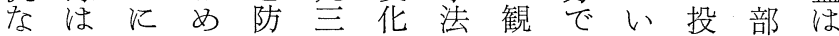

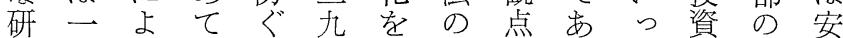
究つつ大た年長適にった航定 ののて切め期用立て限他路し 源産、なに至ににでらので 泉業 経こと互機て あれ分の方 と発党とら間っ 会文らた野低し

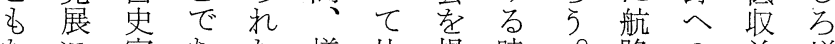
なに家あた様比提時。路の益増 りつ注る 諸々 較供、投を加

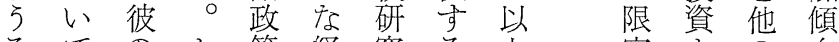
るてのと策経究る上定よの向

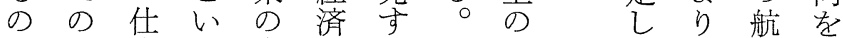
で記事 5 有的る第分路た あ述学の効・た営な析なの学 る的よ性技め加業拈高つ 説り、坚の、術、有収た 明深々つ的デと次年利益。

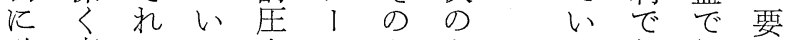
確広にて 力及よるる

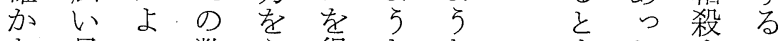

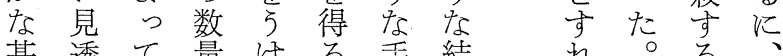
基透て 量的る录結和。る 礎し 資的た究法論 洁しこ海

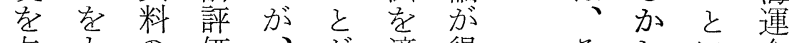

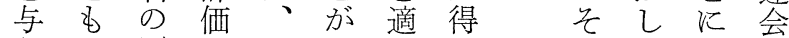
党つ正を学で用ら社

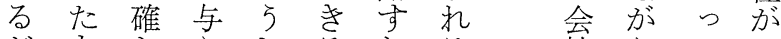

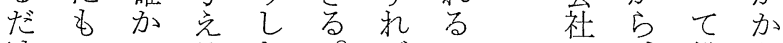
防のつるた た で定こ变第、焉資。收り な 量之化豆海乃金乙益良

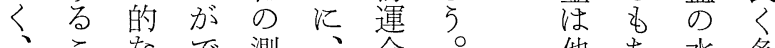

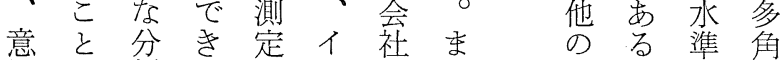
思が析るやギの方や海を化 決で方。立り成第業運維し 定さ可こた不長—会持た のる 能の過海度に投社荝業

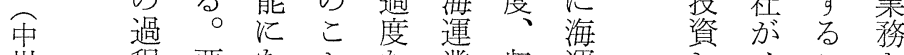

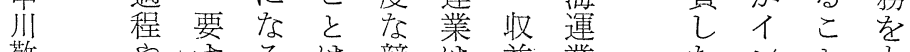

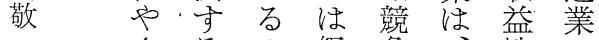

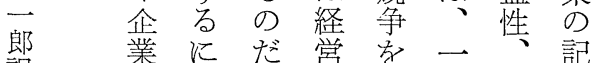

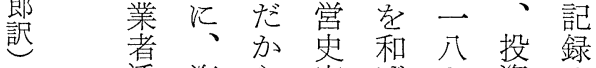
活海ら家活七資情
たンとを

方ドがっ がとでて よかきい りメたる 
経営史学

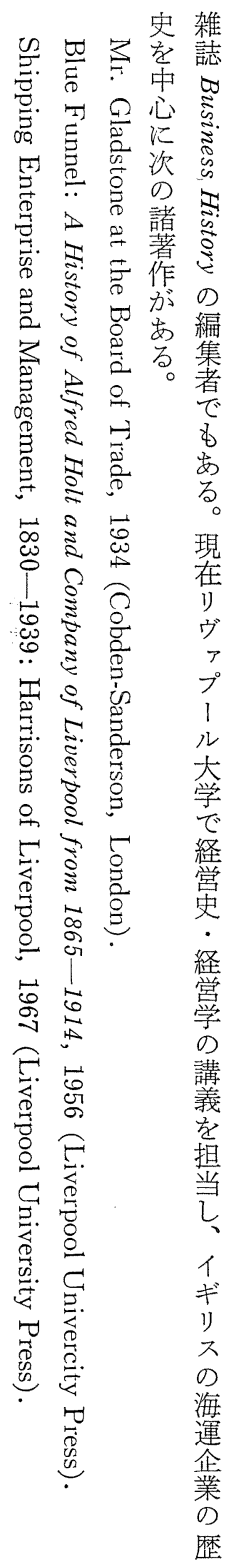




\title{
The Business of Shipping
}

\author{
by \\ Professor Francis E. Hyde \\ University of Liverpool
}

Shipping industry is a fruitful field for business history studies. Earnings of shipping firms depend on the various factor such as the level of demand for the products carried, the effectiveness of competition on the structure of freight rates, the technical efficiency of the ship and the amount of shipping space on offer at a berth at any particular time in relation to the amount of cargo to be lifted.

Over the past sixty years, the fluctuation of net earning from British shipping service has been very wide and the British shipowners maintained a competitive structure by building up reserves in good years from which to sustain building programmes during the poor years.

By offering regular service, the Conference lines increased the commercial tempo of the countries which they served and safeguarded their capital by maintaining earning capacity, sustaining the efficiency of the shipping industry as a whole.

Before 1939, the British fleets of cargo-liners were rebuilt twice. The first rebuilding, from 1885 to 1897 , incorporated the change from compound to triple-expansion engines, the replacement of iron with steel, new system of ventilation and so on. The second reconstruction occurred between 1924 and 1929, switching from steam to diesel propulsion. The second change-over was less comprehensive because Britain was still a coal-based economy.

For the shipping company which had a reasonably well diversified trade, it was still profitable to put capital into ships. If, however, a shipping line confined its activities to a limited number of routes, the investment of the company's resources in alternative enterprise would have been a prudent course to have taken. 